\title{
Student Facilitator and Explaining in Improving Student Social Skills: Assertive Behavior in Opinion and Communication
}

\author{
Rifka Anisa \\ Graduate School \\ Universitas Negeri Yogyakarta \\ Yogyakarta, Indonesia \\ rifkaanisa.2017@student.uny.ac.id
}

\author{
Ali Mustadi \\ Graduate School \\ Universitas Negeri Yogyakarta \\ Yogyakarta, Indonesia \\ ali_mustadi@uny.ac.id
}

\author{
Udik Budi Wibowo \\ Graduate School \\ Universitas Negeri Yogyakarta \\ Yogyakarta, Indonesia \\ udik_bw@uny.ac.id
}

\begin{abstract}
This study was aimed at improving assertive behavior which is one aspect of social skills using Student Facilitator and Explaining (SFAE) method of semester VI students in the Social Studies concentration class of Elementary School Teacher Education UMM. This type of research was classroom action research. Kemmis \& McTaggart model was used as the design research. The research subjects included the semester IV students in the Social Studies concentration class at the Elementary School Teacher Education UMM with a total of 40 students. The object of research was assertive behavior. Data collection techniques that used in this research were questionnaires and observations. Data analysis techniques were carried out in descriptive quantitative approach. The results showed an increase in the average of overall class score. These results indicated that SFAE method positively influences social skills in students especially in assertive behavior. This finding implies that SFAE is an alternative learning method that can be applied to improve student assertive behavior.
\end{abstract}

Keywords- student facilitator and explaining; assertive behavior

\section{INTRODUCTION}

The problems that occur in Elementary School Teacher Education students at Universitas Muhammadiyah Magelang (UMM) in each class are the number of students who still play cellphones during lectures, lack of learning motivation, too many complaints when given assignments, and talking with friends when lecturers explain or when there are students who do presentation. The lecturing process methods used by lecturers are generally lectures, practices, discussions, and group presentations. However, the problems mentioned above are still repeated every semester.

The condition of Elementary School Teacher Education students at UMM in the sixth semester of Social Science concentration shows that assertive behavior still needs to be improved. This is indicated by students who are still lack of self-confidence, low communication skills with less than half of students expressing their opinions, and many students talking with their friends when the lecturer is explaining, or other students are presenting.
Every individual in establishing social relations must have the courage to communicate. Individuals who have the courage to communicate means being able to behave assertively, because one form of this behavior is the courage to communicate. Assertive behavior is part of social skills, namely the ability to express feelings where these skills are useful for interacting, communicating and participating in groups [1].

Assertive behavior really needs to be owned by students, especially prospective teacher students. Regulation of the Minister of National Education of the Republic of Indonesia Number 16 of 2007 Concerning Academic Qualification Standards and Teacher Competencies, teachers must have 4 types of competencies, among others: pedagogic, personality, professional and social competencies. Based on the ministerial regulation above, it clearly stated the competencies that must be possessed by each teacher, one of it is social competence. Social skills are considered as part of the construction of broader social competencies, one of the social skills of assertion skills [2].

The learning method that will be proposed to improve student assertive behavior is Student Facilitator and Explaining (SFAE) model. SFAE is one method in the cooperative learning model in the form of presenting ideas / opinions to other fellow students, this method can be used to practice socializing and participating skills. This study intends to improve assertive behavior of students using SFAE method.

\section{LITERATURE REVIEW}

\section{A. Assertive Behavior}

Assertive behavior is one aspect of social skills. Aspects of social skills include skills related to friends, self-management skills, academic skills, adherence, and assertive behavior [3]. Assertive behavior as an expression of right emotions towards others [4] [5].

Assertive skills are the ability of individuals to make statements in extroverted (openly) way and friendly to others but also remain firm [6]. Assertive behavior can lead to high self-esteem and good 
interpersonal relationships [7]. Then it can be concluded that assertive behavior is one aspect of skills that is able to show emotional expression by behaving appropriately towards others so that they can communicate well.

Assertive individuals can express feelings honestly to others, reject friend invitations that are not in accordance with their wishes, be able to open themselves to others, and be confident [3]. Assertive is seen in terms of education, which is part of social skills which include cooperation, responsibility, and selfcontrol [8]. Assertiveness can also be shown by empathy [9].

Assertive skills include skills to defend their rights, help others, give instructions, express complaints, respond to complaints, negotiate, control themselves, convince others, respond to persuasion, and face pressure from group [10]. In addition, assertiveness can be demonstrated by direct, honest and in-place expression of one's thoughts, feelings, needs, or rights without reasonable anxiety [11]. Assertiveness is also indicated by firmness, daring to express opinions [12]. This assertive behavior includes aspects namely the ability to express opinions, the ability to openly communicate with others, and the ability to defend personal rights.

\section{B. Student Facilitator and Explaining}

Student Facilitator and Explaining learning method (SFAE) is one of the methods in the cooperative learning model. Cooperative learning is a model that offers many ways to increase the number of active students participating in the learning process by telling them to cooperate in small groups [13]. The principles of cooperative learning are heterogeneous grouping, teaching collaborative skills, group autonomy, peer interaction, equal opportunity to participate, individual accountability, positive interdependence, and cooperation as values [14]. The purpose of forming groups in cooperative learning is to provide opportunities for all students to be actively involved in the process of thinking and teaching and learning activities [15].

SFAE method is a method that provides opportunities for students to present ideas or opinions to other participants. Research shows that social learning experiences which are often called groups or cooperative learning in class can have a positive effect on young people [16].

There are six steps in implementing SFAE learning model [17], namely as follows:

1) Lecturers convey the competencies to be achieved.

2) Lecturers demonstrate or present material.

3) The lecturer divides students into groups in heterogeneity. The lecturer instructs students to make concept charts/maps.

4) Providing opportunities for students to explain to each other students for example through concept charts/maps. In this stage the lecturer provides an opportunity for students to explain to other students for example through concept charts/maps.

5) The lecturer summarizes the ideas/opinions of students.

6) The lecturer explained all the material presented at that time.

7) Closing

\section{MATERIAL \& METHODOLOGY}

\section{A. Data}

In this study, the research instruments that researchers used to collect data were questionnaires and observations followed by analyzing research data. The steps in analyzing data in this study were: quantitative data analysis and descriptive data analysis.

In this study quantitative data was in the form of questionnaires. Questionnaire for assertive behavior in the form of a Likert scale. Quantitative data analysis techniques in the form of a questionnaire to determine the level of assertiveness of students. The following were the steps to categorize the level of assertive behavior of students in this study [18].

1) Determine the highest and lowest scores.

2) Calculate ideal score (M) which is $1 / 2$ (highest score + lowest score)

3) Calculate standard deviation (SD) which is $1 / 6$ (highest score - lowest score).

TABLE I. CATEGORIZE THE LEVEL OF ASSERTIVE BEHAVIOR

\begin{tabular}{|l|l|l|}
\hline \multicolumn{1}{|c|}{ Margin Interval } & \multicolumn{1}{|c|}{ Category } & \multicolumn{1}{|c|}{ Margin Interval } \\
\hline Score $<(\mathrm{M}-1 \mathrm{SD})$ & Low & Score $<(\mathrm{M}-1 \mathrm{SD})$ \\
\hline $\begin{array}{l}(\mathrm{M}-1 \mathrm{SD}) \leq \text { Score }< \\
(\mathrm{M}+1 \mathrm{SD})\end{array}$ & Fair & $\begin{array}{l}(\mathrm{M}-1 \mathrm{SD}) \leq \text { Score }< \\
(\mathrm{M}+1 \mathrm{SD})\end{array}$ \\
\hline Score $\geq(\mathrm{M}+1 \mathrm{SD})$ & High & Score $\geq(\mathrm{M}+1 \mathrm{SD})$ \\
\hline
\end{tabular}

\section{B. Method}

This study used Classroom Action Research method. The purpose of this study was to improve assertive behavior of Elementary School Teacher Education students at Universitas Muhammadiyah Magelang (UMM). This study consisted of two variables, namely the dependent variable in the form of assertive behavior, while the independent variable was SFAE method. This research was conducted in the class of sixth semester of Elementary School Teacher Education UMM from April to May 2018. The subjects in this study were the sixth semester students of the Social Sciences concentration class at Elementary School Teacher Education UMM, with the total of 40 students. While the object of this research was assertive behavior in students carried out in two cycles, started with planning, then carrying out action and observation, and reflection as in the following picture: 


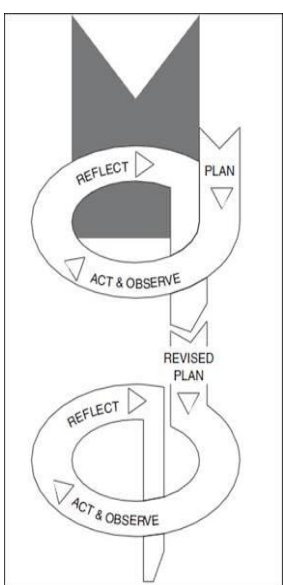

Explanation:

Cycle I:

1. Planning I

2. Action and Observation, I

3. Reflection I

Cycle II:

1. Planning II

2. Action and Observation II

3. Reflection II

Fig 1. Kemmis Mc. Taggart Spiral Model [19]

\section{RESULTS AND DISCUSSION}

\section{A. Results}

This research was conducted at Elementary School Teacher Education UMM, because based on the observation done by the researchers, there was a class of Elementary School Teacher Education study program at UMM still had assertive behavior below $50 \%$ on average. Before the research was conducted, the researcher first conducted observations and interviews with the Head of Department and lecturers who had taught the class. The interview was conducted by the researcher by asking students' self-confidence in expressing the opinions and activeness of students. The lecturer stated that the sixth semester students in the Social Science concentration class had a sense of confidence and activity which was still below $50 \%$. While based on the results of the observation data, it was found that only $21 \%$ of all students were active in expressing their opinions and asking questions. After the researcher gave the action and gave the following questionnaire, the results of the questionnaire were obtained.

TABLE II. QUESTIONNAIRE RESULTS OF OPINION ABILITY IN

\begin{tabular}{|c|c|c|c|c|c|}
\hline $\begin{array}{c}\text { Sub } \\
\text { Indicator }\end{array}$ & $\begin{array}{c}\text { Average } \\
\text { Score }\end{array}$ & $\begin{array}{c}\text { Total } \\
\text { Scor } \\
e\end{array}$ & $\begin{array}{c}\text { Ideal } \\
\text { Scor } \\
e\end{array}$ & $\%$ & Category \\
\hline \multicolumn{6}{|c|}{ Expressing feelings honestly with others } \\
\hline $\begin{array}{l}\text { Expressing } \\
\text { feelings }\end{array}$ & 2.75 & \multirow[t]{8}{*}{$\begin{array}{c}26.8 \\
5\end{array}$} & \multirow[t]{8}{*}{25} & \multirow[t]{8}{*}{$\begin{array}{l}67 . \\
13\end{array}$} & \multirow[t]{8}{*}{ Fair } \\
\hline $\begin{array}{l}\text { Uttering } \\
\text { feelings }\end{array}$ & 2.75 & & & & \\
\hline $\begin{array}{l}\text { Arguing } \\
\text { based on } \\
\text { their own } \\
\text { belief }\end{array}$ & 3.35 & & & & \\
\hline $\begin{array}{l}\text { Expressing } \\
\text { opinions }\end{array}$ & 2.45 & & & & \\
\hline $\begin{array}{l}\text { Expressing } \\
\text { resentment }\end{array}$ & 2.3 & & & & \\
\hline $\begin{array}{l}\text { Do not hide } \\
\text { the feelings }\end{array}$ & 2.525 & & & & \\
\hline Honest & 3.325 & & & & \\
\hline $\begin{array}{l}\text { Able to } \\
\text { convey the } \\
\text { truth even } \\
\text { though it } \\
\text { hurts }\end{array}$ & 2.1 & & & & \\
\hline
\end{tabular}

\begin{tabular}{|c|c|c|c|c|c|}
\hline $\begin{array}{l}\text { Expressing } \\
\text { happy } \\
\text { feelings }\end{array}$ & 2.85 & & & & \\
\hline $\begin{array}{l}\text { Do not } \\
\text { conceal } \\
\text { feelings }\end{array}$ & 2.45 & & & & \\
\hline \multicolumn{6}{|c|}{ Refuse friend invitations that are not as desired } \\
\hline $\begin{array}{l}\text { Refuse } \\
\text { invitations } \\
\text { that gave a } \\
\text { negative } \\
\text { impact }\end{array}$ & 3.45 & 23 & 20 & $\begin{array}{l}71 . \\
86\end{array}$ & Fair \\
\hline $\begin{array}{l}\text { Refuse } \\
\text { requests that } \\
\text { do not match } \\
\text { capabilities }\end{array}$ & 2.225 & & & & \\
\hline $\begin{array}{l}\text { Courageousl } \\
\text { y rejected the } \\
\text { request }\end{array}$ & 2.85 & & & & \\
\hline $\begin{array}{l}\text { Easily reject } \\
\text { bad friend's } \\
\text { invitations }\end{array}$ & 3.075 & & & & \\
\hline $\begin{array}{l}\text { Able to } \\
\text { maintain self- } \\
\text { confidence }\end{array}$ & 2.5 & & & & \\
\hline $\begin{array}{l}\text { Refusing } \\
\text { adverse } \\
\text { invitation }\end{array}$ & 3.1 & & & & \\
\hline $\begin{array}{l}\text { Not easily } \\
\text { affected }\end{array}$ & 2.925 & & & & \\
\hline Resolute & 2.875 & & & & \\
\hline
\end{tabular}

The results of the cycle I questionnaire on the first indicator show that the two sub indicators show that the category reaches fair level. In the first sub-indicator reached a score of 26.85 with an ideal score of 25 and in the second sub indicator reached a score of 23 with an ideal score of 20. This shows assertive behavior in the first indicator has reached the ideal score. While the second indicator can be seen in table 3 below.

TABLE III. QUESTIONNAIRE RESULTS OF COMMUNICATION ABILITY IN CYCLE 1

\begin{tabular}{|c|c|c|c|c|c|}
\hline Sub Indicator & $\begin{array}{l}\text { Averag } \\
\text { e Score }\end{array}$ & $\begin{array}{l}\text { Total } \\
\text { Score } \\
\end{array}$ & $\begin{array}{l}\text { Ideal } \\
\text { Score }\end{array}$ & $\%$ & $\begin{array}{l}\text { Cate } \\
\text { gory }\end{array}$ \\
\hline \multicolumn{6}{|c|}{ Able to open to others } \\
\hline $\begin{array}{l}\text { Able to start a } \\
\text { conversation }\end{array}$ & 3.075 & \multirow[t]{6}{*}{16.36} & \multirow[t]{6}{*}{15} & \multirow[t]{6}{*}{$\begin{array}{l}68 . \\
23\end{array}$} & \multirow[t]{6}{*}{ Fair } \\
\hline $\begin{array}{l}\text { Openly } \\
\text { deliver the } \\
\text { feelings }\end{array}$ & 2.85 & & & & \\
\hline Assertive & 2.65 & & & & \\
\hline Brave & 2.8 & & & & \\
\hline $\begin{array}{l}\text { Able to } \\
\text { communicate }\end{array}$ & 2.575 & & & & \\
\hline $\begin{array}{l}\text { Express } \\
\text { opinions } \\
\text { according to } \\
\text { facts }\end{array}$ & 2.425 & & & & \\
\hline \multicolumn{6}{|c|}{ Confidence } \\
\hline $\begin{array}{l}\text { Able to appear } \\
\text { in public }\end{array}$ & 2.5 & \multirow[t]{4}{*}{11.16} & \multirow[t]{4}{*}{10} & \multirow[t]{4}{*}{$\begin{array}{l}69 . \\
84\end{array}$} & \multirow[t]{4}{*}{ Fair } \\
\hline $\begin{array}{l}\text { Willing to } \\
\text { answer the } \\
\text { question in } \\
\text { public }\end{array}$ & 2,775 & & & & \\
\hline $\begin{array}{l}\text { Confident in } \\
\text { his/her } \\
\text { appearance }\end{array}$ & 3,125 & & & & \\
\hline $\begin{array}{l}\text { Not easy to be } \\
\text { shy }\end{array}$ & 2,775 & & & & \\
\hline
\end{tabular}


The results of the cycle I questionnaire on the second indicator showed that the two sub indicators show that the category reaches fair level. In the first sub-indicator reached a score of 16.36 with an ideal score of 15 and in the second sub-indicator reached a score of 11.16 with an ideal score of 10 . This shows assertive behavior in the first indicator has reached the ideal score. The results of the cycle I questionnaire showed that there is an increase in assertive behavior on each indicator with an average increase to $69.11 \%$. However, all 4 sub-indicators were still in the fair category. The results of individual assertive behavior questionnaires obtained in cycle I were 5 out of 40 students had a high category and 35 students had a fair category. The following is a table of results of the assertive behavior questionnaire in cycle 1 .

TABLE IV. RESUlTS OF QUESTIONNAIRE CYCLE 1: STUDENT ASSERTIVE BEHAVIOR INDIVIDUALLY

\begin{tabular}{|l|c|c|c|}
\hline No & Category & Total Students & \% \\
\hline 1. & Low & 0 & 0 \\
\hline 2. & Fair & 35 & 87.5 \\
\hline 3. & High & 5 & 12.5 \\
\hline
\end{tabular}

The results of observations in the cycle I showed that students had begun to actively express their opinions by looking at the other person, but there were still 12 students who looked down when expressing their opinions while explaining with other participants. Facial expressions are appropriate when students submit material or ask questions. The physical distance at the first meeting still had two students who were seen moving away from the discussion group, while at the second meeting the physical distance position had begun to blend. Meanwhile, the tone of voice when explaining has sounded clear and firm. Assessment of the success of the cycle I was also carried out by giving questionnaires to students.

Based on the questionnaire data above, it can be concluded that the assertive behavior of the sixth semester students in the Social Sciences concentration class both as an indicator and individually was still classified as fair category, but it has exceeded the ideal score. Assessment of the success of cycle II is also done by giving questionnaires to students. Indicator results obtained in cycle II are as follows.

TABLE V. QUESTIONNAIRE RESULTS OF OPPINION ABILITY IN CYCLE 2

\begin{tabular}{|l|c|c|c|c|c|}
\hline $\begin{array}{c}\text { Sub } \\
\text { Indicator }\end{array}$ & $\begin{array}{c}\text { Average } \\
\text { Score }\end{array}$ & $\begin{array}{c}\text { Total } \\
\text { Score }\end{array}$ & $\begin{array}{c}\text { Ideal } \\
\text { Score }\end{array}$ & $\%$ & Category \\
\hline \multicolumn{5}{|c|}{ Expressing feelings honestly with others } \\
\hline $\begin{array}{l}\text { Expressin } \\
\text { g feelings }\end{array}$ & 2.8 & 26.85 & 25 & 67. & Fair \\
\cline { 1 - 2 } $\begin{array}{l}\text { Uttering } \\
\text { feelings }\end{array}$ & 2.825 & & & 13 & \\
\cline { 1 - 1 } $\begin{array}{l}\text { Arguing } \\
\text { based on } \\
\text { their own } \\
\text { belief }\end{array}$ & 3.225 & & & & \\
\hline
\end{tabular}

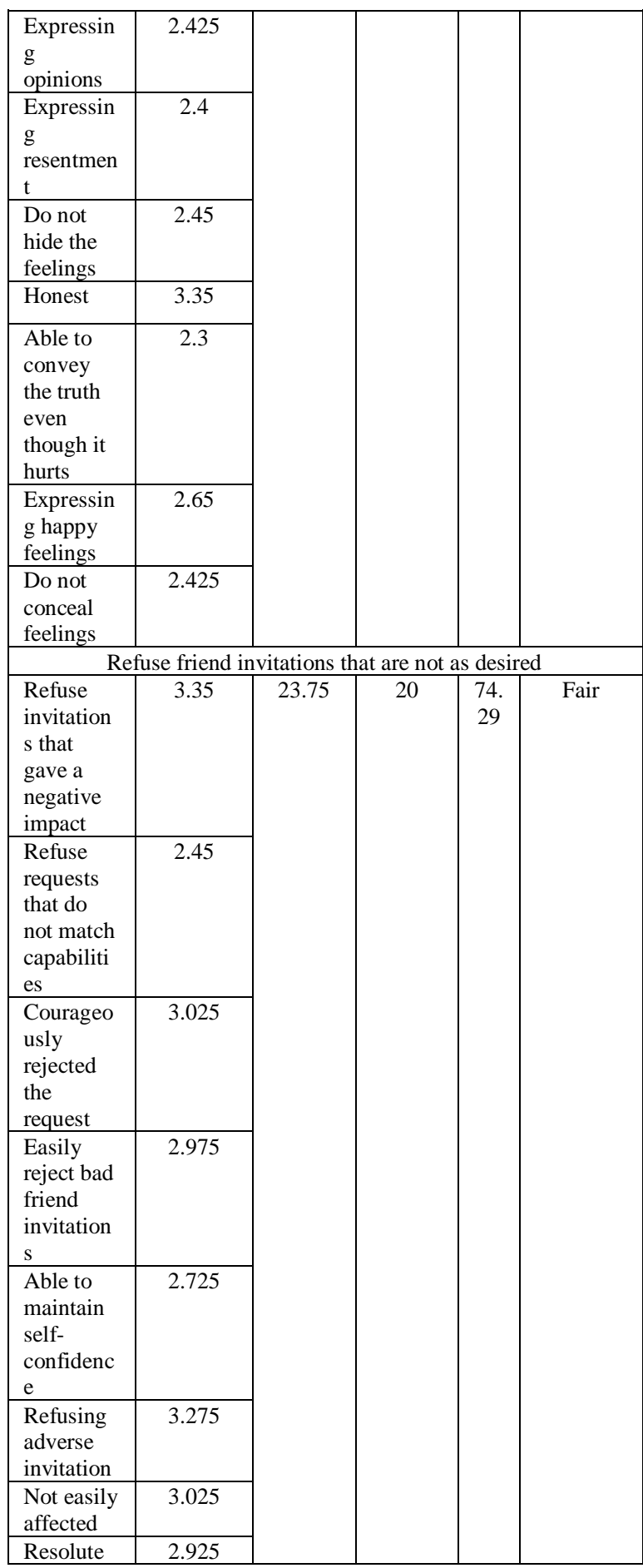

The result of the cycle II questionnaire on the first indicator showed that the two sub indicators show that the category reached the fair level. In the first subindicator reached a score of 26.85 with an ideal score of 25 and in the second sub-indicator reached a score of 23.75 with an ideal score of 20 . It shows that assertive behavior in the first indicator has reached the ideal score and has increased in the second sub-indicator into $2.43 \%$. While the second indicator can be seen in the Table 6 below. 
TABLE VI. QUESTIONNAIRE RESULTS OF COMMUNICATION ABILITY IN CYCLE 2

\begin{tabular}{|c|c|c|c|c|c|}
\hline $\begin{array}{c}\text { Sub } \\
\text { Indicator }\end{array}$ & $\begin{array}{c}\text { Average } \\
\text { Score }\end{array}$ & $\begin{array}{l}\text { Total } \\
\text { Score }\end{array}$ & $\begin{array}{l}\text { Ideal } \\
\text { Score }\end{array}$ & $\%$ & Category \\
\hline \multicolumn{6}{|c|}{ Able to open to others } \\
\hline $\begin{array}{l}\text { Able to } \\
\text { start a } \\
\text { conversati } \\
\text { on }\end{array}$ & 2.9 & \multirow[t]{6}{*}{16.48} & \multirow[t]{6}{*}{15} & \multirow[t]{6}{*}{$\begin{array}{l}68 . \\
65\end{array}$} & \multirow[t]{6}{*}{ Fair } \\
\hline $\begin{array}{l}\text { Openly } \\
\text { deliver the } \\
\text { feelings }\end{array}$ & 2.7 & & & & \\
\hline Assertive & 2.825 & & & & \\
\hline Brave & 2.875 & & & & \\
\hline $\begin{array}{l}\text { Able to } \\
\text { communic } \\
\text { ate }\end{array}$ & 2.7 & & & & \\
\hline $\begin{array}{l}\text { Express } \\
\text { opinions } \\
\text { according } \\
\text { to facts }\end{array}$ & 2.475 & & & & \\
\hline \multicolumn{6}{|c|}{ Confidence } \\
\hline $\begin{array}{ll}\text { Able } & \text { to } \\
\text { appear } & \text { in } \\
\text { public } & \end{array}$ & 2.725 & \multirow[t]{4}{*}{11.65} & \multirow[t]{4}{*}{10} & \multirow[t]{4}{*}{$\begin{array}{l}72 . \\
81\end{array}$} & \multirow[t]{4}{*}{ Fair } \\
\hline $\begin{array}{l}\text { Willing to } \\
\text { answer the } \\
\text { question in } \\
\text { public }\end{array}$ & 2.875 & & & & \\
\hline $\begin{array}{l}\text { Confident } \\
\text { in his/her } \\
\text { appearanc } \\
\mathrm{e}\end{array}$ & 3.15 & & & & \\
\hline $\begin{array}{l}\text { Not easy } \\
\text { to be shy }\end{array}$ & 2.9 & & & & \\
\hline
\end{tabular}

The results of the cycle II questionnaire on the second indicator showed that the two sub indicators show that the category reached fair level. In the first sub-indicator reached a score of 16.48 with an ideal score of 15 and in the second sub-indicator reached a score of 11.65 with an ideal score of 10 . It shows that assertive behavior in the first indicator has reached the ideal score and the two sub-indicators have increased. In the first sub-indicator increases by $0.42 \%$ and the second sub-indicator 2 increases by $2.97 \%$. The results of the cycle II questionnaire indicate that there was an increase in assertive behavior on each indicator with an average increase to $70.29 \%$. However, all 4 sub indicators were still in the fair category. While the results of individual questionnaires from 40 students are as follows.

TABLE VII. RESULTS OF QUESTIONNAIRE CYCLE 2: STUDENT ASSERTIVE BEHAVIOR INDIVIDUALLY

\begin{tabular}{|c|c|c|c|}
\hline No & Category & Total Students & \% \\
\hline 1. & Low & 0 & 0 \\
\hline 2. & Fair & 32 & 80 \\
\hline 3. & High & 8 & 20 \\
\hline
\end{tabular}

Based on the questionnaire data above, it can be concluded that the assertive behavior of the sixth semester students in the Social Science concentration class both as an indicator and individually increased even though the fair category still dominated. However, it has exceeded the ideal score and the high category has increased. The results of the recap of increasing assertive behavior are as follows.
The Increase of Assertive Behavior

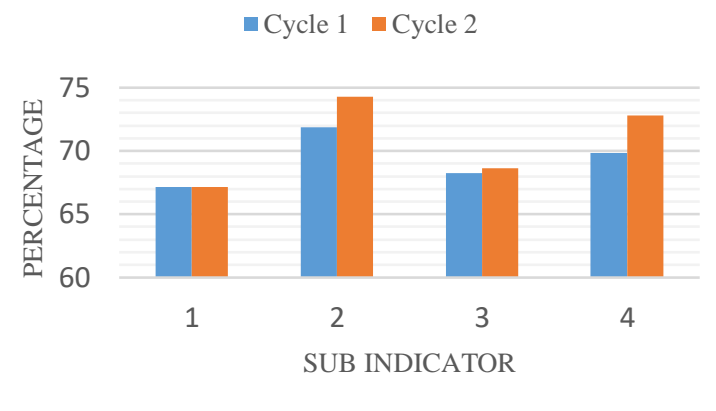

Fig. 2. Increasing the Average Score of Assertive Behavior

The results of observations in the cycle II showed that students were actively expressing their opinions by looking at the other person, but there were still 4 students who looked down when expressing their opinions during the third meeting, when the fourth meeting began to appear the students dared to look directly at the other person. Facial expressions are appropriate when students submit material or ask questions. Physical distance has seen the physical distance position begin to blend. The voice when explaining is clear and firm.

\section{B. Discussion}

This research was conducted in two cycles. Each cycle was carried out in two meetings. The action taken was by applying Student Facilitator and Explaining learning method. The results of the action in the cycle I and cycle II showed an increase in each cycle. Assertive behavior is an important behavior possessed by individuals in dealing with relationships in the social environment. It is needed for honest and healthy relationships. Conversely, non-assertive individuals tend to be very anxious in interpersonal relationships and fail to achieve their goals.

This action research was conducted to improve assertive behavior of UMM Elementary School Teacher Education students by applying Student Facilitator and Explaining learning method. Student Facilitator and Explaining learning method was chosen because this method is done by presenting ideas or opinions to other fellow students. This method can be used to practice socializing and participating skills. In addition, this method aims to teach individuals to develop individual social skills which include skills to initiate social interactions with others, express feelings, behave assertively, and solve problems.

From the results of the study, it was found that there was an increase in assertive behavior of UMM Elementary School Teacher Education students. The results of this study indicate that assertive behavior on the subject on the two indicators, namely being able to express opinions and be able to communicate with 
others described in four sub-indicators, namely expressing feelings honestly to others, rejecting friend's invitation that is not in accordance with the wishes, able to open up to other people, and the increased of confidence. This can be seen from the observation that shows that students have increased their self-esteem which is marked by the reduced number of students looking down while explaining the material to other students. The habit of talking in front of friends makes students trained in self-confidence. In addition, there was an increase in the physical distance of the students which initially had two students who seemed to move away from the discussion, had been seen mingling during the discussion. Student facial expressions and voices were very appropriate when asking questions and conveying answers or explaining material.

The class average score for each indicator increases in each cycle. It can be concluded that from the score of cycle I to cycle II the value in sub-indicator 1 of $67.13 \%$ remains $67.13 \%$. The first sub indicator, which is expressing feelings honestly, has not increased. However, when compared with the initial conditions the number of students who want to express their opinion has increased. This is because SFAE method emphasizes communication skills [17].

In sub-indicator 2 there is an increase from $71.88 \%$ to $74.22 \%$. This second sub indicator is rejecting the invitation of a friend who is not as desired. In line with theory, cooperative learning demands to be responsible for themselves and their groups [20]. Therefore, if students are easily influenced by things that are not good, then students will feel loss. For example, when lecturing, he prefers to speak something that is not important so he is unable to return the material to his group friends, so when the quiz is held the group gets a bad score.

In sub-indicator 3 there is an increase from $68.23 \%$ to $68.65 \%$. The third sub indicator is being able to open up to others. Learning using Student Facilitator and Explaining method trains students to express their ideas to practice courage to speak. Then there are group discussions and questions and answers when presentations, there is a process of exchange of ideas that makes students who do not understand become understand and who do not know become know. This is because SFAE method is a model that provides opportunities for students or participants to present ideas or opinions to other participants [17].

On sub-indicator 4 , it increased from $69.84 \%$ to $72.81 \%$. The 4 th sub indicator is self-confidence. Social learning experiences that are often called groups or cooperative learning in class can have a positive effect on young people [16]. This causes increased confidence in students.
While seen individually, the behavior of the cycle I to the cycle II also increased. In the percentage of assertive behavior individually experienced an increase in the high category starting from $12.5 \%$ in the cycle I then increasing to $20 \%$ in the cycle II. While in the fair category it was experiencing a decline, in the medium category ranging from $87.5 \%$ to $80 \%$. While in the low category it remains at $0 \%$.

Based on the discussion of the results of the above research, it can be said that by applying Student Facilitator and Explaining method can improve assertive behavior of the sixth semester students in the Social Studies concentration class of Elementary School Teacher Education UMM.

\section{CONCLUSION}

Based on the research findings and discussion of the results of the study, it can be concluded that lectures using Student Facilitator and Explaining method can improve student assertive behavior. With these activities, students will be accustomed in expressing opinions, exchanging thoughts, and having selfconfidence so it can increase the assertive behavior.

\section{ACKNOWLEDGMENT}

Thank you for the assistance given to those who have helped, both lecturers, colleagues, and writers that we refer to his thoughts. The researchers hope that this article can be useful for the reader.

\section{REFERENCES}

[1] P. Vagos, A. Pereira, and C. M. Warner, "Effectiveness of skills for academic and social success (SASS) with portuguese adolescents," International Journal of Group Psychotherapy, vol. 65 , pp. 135-147, 2015.

[2] S. Jurkoski and M. Hänze, "A closer look at social skills and school performance: Students' peer relations skills and assertion skills as predictors for their written and oral performances," Eur J Psychol Educ, 2015.

[3] K. Merrell, Behavioral Social and Emotional Assessment of Children and Adolescent. New Jersey: Lawrence Erlbaum Associates, 2003.

[4] T. Rasyid, "Development of social skill among children at elementary level," Bulletin of Education and Research, vol. 3, pp. 69-78, 2010.

[5] E. Walker, Clinical Procedures for Behavior Therapy. New Jersey: Prentice Hall, 1981.

[6] P. G. Gimpel and W. K. Merrell, Practical Handbook of School Psychology. New York: The Guildford Press, 2009.

[7] P. D. C. Widjaja and R. Wulan, "Hubungan antara asertivitas dan kematangan dengan kecenderungan neurotik pada remaja," Jurnal Psikologi, vol.25, pp. 56-62, 1998.

[8] J. Sivin-Kachala and E. Bialo, IESD Comprehensive Technical Report, Evaluation of Full-Time, Online PublicSchool Students. New York: Interactive Educational Design (IESD) Inch, 2009

[9] L. Golden, Evaluation of the efficiency of a cognitive behavioral program for offenders on probation: Thinking for a change. Dallas: University of Texas Southwestern Medical Center, 2002.

[10] P. R. Sprafkin, J. N. Gershaw, and P.A. Goldstein, Social Skills for Mental Health. Massachusetts: Allyn and Bacon, 1993. 
[11] G. Corey, Theory and Practice of Counseling and Psychotherapy. Thomson: Brooks Cole, 2005.

[12] S. J. Stein and H. E.Book, The EQ Edge. Canada: John Wiley \& Sons Canada Ltd, 2006.

[13] Y. Sharan, "Learning to cooperate for cooperative learning," Anales De Psicología, vol. 30, pp. 802-807, 2014.

[14] D. W. Johnson, P.T. Johnson, and E. J. Holubec, Nuts \& Bolts of Cooperative Learning 2nd ed. Edina, MN: Interaction Book Company, 2007.

[15] Trianto, Model-model Pembelajaran Inovatif Berorientasi Konstuktivistik. Jakarta: Prestasi Pustaka, 2007.
[16] C. Igel and V. Urquhart, "Generation Z, meet cooperative learning,” Middle School Journal, vol. 43, 2012, pp.16-21.

[17] A. Suprijono, Cooperative Learning: Teori \& Aplikasi Paikem. Yogyakarta: Pustaka Pelajar, 2009.

[18] S. Azwar, Reliabilitas dan Validitas. Yogyakarta: Pustaka Pelajar, 2001.

[19] W. Kusumah and D. Dwigatama, Mengenal Penelitian Tindakan Kelas. Jakarta: Indeks, 2011.

[20] R E. Slavin, Cooperative Learning. London: Alymand Bacon, 2015. 